\title{
Intertextuality: Interpretive Practice and Textual Strategy
}

\section{Brian Ott and Cameron Walter}

\begin{abstract}
$\square$-In contemporary media scholarship, the concept of intertextuality is used to describe both an interpretive practice of audiences and a stylistic device consciously employed by producers of media. This study examines how the frequent, scholarly conflation of these two conceptions has weakened the theoretical usefulness of both perspectives. Turning to the view of intertextuality as stylistic device, the essay identifies parodic allusion, creative appropriation, and self-reflexive reference as three distinct intertextual strategies. It concludes by considering the ways audiences use these devices to define their identities and order their experiences.
\end{abstract}

VER the course of the past three decades, the post-structuralist notion of intertextuality has rapidly acquired intellectual currency among media scholars. Ironically, the rise of this concept was initiated and then fueled by two somewhat divergent forces. In the early 1970 s, media scholars-drawing upon the critique of the "AuthorGod" by semoticians and literary theorists such as Barthes (1988), Derrida (1976), and Kristeva (1986a, 1986b)began theorizing the notion of the "active audience." In this tradition, intertextuality served as a descriptor for the general process by which audiences create meaning. Then, in the early 1980 s, media critics observed that film

Brian Ott is Assistant Professor of Media Stud ies in the Department of Speech Communication at Colorado State University, Fort Collins, CO 80523. Cameron Walter is an undergraduate student in the same department. An earlier version of this paper was presented at the Western States Communication Association Convention in February 2000. and television shows had increasingly begun quoting and referencing other popular cultural artifacts. Seeking to describe this phenomenon, criticsboth academic (Campbell \& Freed, 1993; Collins, 1992) and popular (Bark, 1998; Griffin, 1998)-adopted the term intertextuality. The centering of the audience as a site of textual production and the expanding role of intentional allusion in media has contributed to and continues to animate a largely unnoticed duality in the use of the concept. ${ }^{1}$ Hence, in current practice, media scholars employ the term intertextuality to describe two extremely different phenomena. ${ }^{2}$

Television critic John Fiske, for instance, uses intertextuality to describe the way audiences unconsciously create meaning by utilizing their vast knowledge of cultural codes learned from other texts to read a particular text. For Fiske $(1987,1989)$, intertextuality is a postmodern sensibility shared by audiences-a reading formation that conceives of texts as fragments in a larger

Copyright 2000, National Communication Association 
web of textuality. "The theory of intertextuality," he writes, "proposes that any one text is necessarily read in relationship to others and that a range of textual knowledges is brought to bear upon it. These relations do not take the form of specific allusions from one text to another and there is no need for readers to be familiar with specific texts to read intertextually" (1987, p. 108) Though reading intertextually does not require specific textual knowledges, there are nonetheless some texts that make specific allusions, that invite readers to exercise specialized knowledge, and this too has been termed intertextuality.

In this latter formulation, intertextuality is not something audiences do, but something authors do. Far from being a consequence of the death of the author (as the first version would suggest), intertextuality is an identifiable stylistic device consciously employed by the author or in the case of media texts by the producer, to invite a particular audience response. ${ }^{3} \mathrm{Jim} \mathrm{Col}-$ lins (1992) highlights this perspective in his discussion of television's postmodern elements:

The foregrounding of intertextual references has become a marker of "quality television."... Jane Feuer has traced this self-conscious intertextuality as it developed in the MTM style, but more recently, as "quality television" has developed across production companies and networks, the explicit referencing has played a vital role in situating a given program in relation to other forms of quality and nonquality programs. During the 1990 fall season, for example, Michael and Hope of ABC's thirtysomething referred to watching $L$. A. Law, while on NBC's $L$. A. Law, attorney Anne Kelsey spoke of wanting to get home and watch thirtysomething because it was "responsible television." (p. 334)
In contrast to Fiske, Collins conceives of intertextuality as inherent to some texts, strategically included by the producer, and referring to specific other texts.

The two preceding examples suggest that intertextuality has been used to describe both an interpretive practice unconsciously exercised by audiences living in a postmodern landscape and a textual strategy consciously incorporated by media producers that invites audiences to make specific lateral associations between texts. Intertextuality has come to describe both the general practice of decoding and a specific strategy of encoding. Unfortunately, media scholars rarely make this distinction, and as the term has spread in popularity, its dual legacy and meaning have increasingly been conflated in the work of practicing critics.

James Goodwin's (1994) study of the films of Akira Kurosawa affords a prime example of this conflation. Citing Kristeva and Barthes, Goodwin argues at the outset of his book that, "the concept of intertextuality designates a multidimensional relation through which a particular text is intelligible [to readers] in terms of other texts" (p. 9). In the pages that follow, he consistently describes the concept as an interpretive practice of audiences. When he begins his criticism of Kurosawa's films, however, he shifts the term's focus from audience to author. "Intertextual cinema," he writes, "is reserved in the present study for films and the work of cineasts that exhibit conscious, marked, or dominant uses of intertextuality... intertextual structures of the director's own design" (p. 16). To the extent that these two conceptions involve very different rhetorical processes, their conflation undermines the explanatory force of intertextuality as a theoretical tool.
This essay reflects an effort to flesh out the differences between these two conceptions, and to restore the term's hermeneutic value. To accomplish this goal, this essay begins by looking at the dual legacy of intertextuality and its adoption by media scholars. Then this essay focuses more closely on the conception of "intertextuality as textual strategy" by arguing for three distinct types, parodic allusion, creative appropriation, and self-reflexive reference. The final portion of the essay explores the "symbolic equipment" (Burke, 1973) that audiences might derive from the various intertextual strategies utilized by media producers.

\section{Intertextuality as \\ Interpretive Practice}

The view of "intertextuality as interpretive practice" represents a direct challenge to the modernist and formalist notions of 'authorial originality' and 'influence' (Hawkes, 1977). "The intertextual in which every text is held," writes Barthes, "is not to be confused with some origin of the text: to try to find the 'sources', the 'influences' of a work, is to fall in with the myth of filiation; the citations which go to make up a text are anonymous, untraceable ... they are quotations without inverted commas" $(1988$, p. 160). Despite subscribing to this view, several scholars (Makaryk, 1995; Payne, 1996) have paradoxically identified Julia Kristeva as the "source" of the term intertextuality and then traced its "development" in subsequent writers. Rather than rehearse and hence perpetuate this narrative yet again, this section identifies some of the key similarities and dissimilarities in how the concept has been used by a number of different literary and media theorists to account for the way readers/audiences come to meaning and experience the world.

One premise widely shared by literary theorists is that intertextuality represents a clear shift in thinking about who creates texts. In describing intertextuality, Barthes argues that audiences, not authors, write (i.e., construct) texts:

We know now a text is not a line of words releasing a single "theological" meaning (the "message" of the Author-God) but a multidimensional space in which a variety of writings, none of them original, blend and clash. The text is a tissue of quotations drawn from innumerable centers of culture.... [A text] is made of multiple writings, drawn from many cultures and entering into mutual relations of dialogue, parody, and contestation, but there is one place where this multiplicity is focused and that place is the reader, not as was hitherto said, the author. (1988, pp. 146, 148)

For Barthes, the reader affords the space upon which a web of textual quotations (i.e., a text) is inscribed; consequently, the "unity of a text lies not in its origin but in its destination" (1980, p. 148). Moreover, a text as constituted by a reader is always fleeting, never finished once and for all. Since a text exists within an endlessly expanding matrix of intertextual production, readers continually bring new texts to bear upon their readings of that text. The reader who returns to an essay or book she has read in the past will find that that text no longer exists, that the rereading has been a rewriting. Intertextuality for Barthes, then, describes the textual 'infinitude' upon which readers unconsciously draw to momentarily give meaning to a text. This view describes how audiences produce readings (i.e., texts) that are always unique and non-unique. Since every reader possesses different textual 
knowledges, they necessarily produce individualized readings. However to the extent that audiences share cultures, which is another way of saying they share texts, they bring some common textual knowledges to bear upon text construction. ${ }^{4}$

Julia Kristeva conceives of textuality in much the same way as Barthes by arguing that "any text is constructed as a mosaic of quotations; any text is the absorption and transformation of [other texts]" (1986b, p. 37). Texts are neither self-contained, nor individually authored; they are endlessly permeated by a social ensemble which is itself a textual ensemble. In elaborating on this endless permeation-this intermingling of sign systems-Kristeva, like Barthes, locates text construction with the audience. She defines intertextuality as a fundamental process in the work of the unconscious in which several sign-systems are transposed into another (1986a, p. 111). According to Kristeva, "The notion of intertextuality replaces that of intersubjectivity" (1986b, p. 37)-the theory that had for merly seen the reading of a text as a "subject-to-subject exchange between author-source and reader-receiver" (Payne, 1996, p. 259). For Kristeva (and it is suspected for Barthes as well, though he is far less explicit about it) intertextuality is a wholly ideological process.

Text generation entails the simultaneous accentuation, condensation, and intermingling of culturally created sign systems. Audiences create texts by, at once, isolating them from other texts and opening them to the endless play of textuality (Derrida, 1976; Scholes, 1989). To identify a specific text is to impose boundaries (such as, but not limited to, genre and form) upon itboundaries that are made meaningful only in relation to the whole web of textuality. To identify a text is to classify it as generically akin to some texts and not others, to read/write it through cultural codes and interpretive conventions learned from other texts. The media critic who discusses Ally $\mathrm{McBeal}$ as a recognizable text has to some extent already read it through the genre of situation-comedy, which is based in turn on a textual knowledge of nonsituation-comedies. While the act of reading is one of cultural/ideological (re)production then, it is also fraught with heterogeneity and contradiction. The infinity of intertextuality ensures that a text will always be plural, un stable, and contradictory

While numerous media scholars have adopted and employed the concept of intertextuality to describe the way audiences read media texts within the larger web of media culture, few have recognized or accepted the full implications or possibilities of the concept as set forth by Barthes and Kristeva. "Most scholars," notes Makaryk, "who use the term have developed a 'restricted' intertextuality which focuses on the relations between several texts. Ironically, this may involve little more than the philological tradition of influence tracing which the term sought to displace" (1995, p. 569). On the surface, for instance, Fiske appears to be consistent with the perspectives articulated by Barthes and Kristeva arguing that "because of their incompleteness, all popular texts have leaky boundaries; they flow into everyday life. Distinctions among texts are as invalid as the distinctions between text and life. Popular culture can only be studied intertextually, for it exists only in this intertextual circulation" $(1989$, p. 126). However, when he details the precise nature of intertextual reading practices, Fiske significantly confines the heterogeneity and infinity of intertextuality. Fiske's restricted conception is evident in both his description of how television programs are intertextually constructed by audiences and how popular culture, in general, is read intertextually:

We can envisage these intertextual relations on two dimensions, the horizontal and the vertical. Horizontal relations are those between primary texts that are more or less explicitly linked, usually along the axes of genre, character, or content. Vertical intertextuality is that between a primary text, such as a television program or series, and other texts of a different type that refer explicitly to it. These may be secondary texts such as studio publicity, journalistic features, or criticism, or tertiary texts produced by the viewers themselves in the form of letters to the press or more importantly, of gossip and conversation. (1987, p. 108)

Popular culture circulates intertextually, among what I have called primary texts (the original commodities-Madonna herself or a pair of jeans), secondary texts that refer to them directly (advertisements, press stories, criticism), and tertiary texts that are in the constant process of everyday life (conversation [about the primary text]). (1989, p. 124)

Rather than exploring how text construction is informed by the whole range of textuality, Fiske limits intertextual reading to a few "primary texts" that are "explicitly linked" and to other texts that refer "explicitly" or "directly" to the primary texts. The unconscious processes and implicit links that inform Barthes' and Kristeva's outlook are ignored.

For Fiske, an intertextual reading of a television show such as The A-Team (1983-87) entails examining the "influence" of studio publicity, gossip, popular criticism, and journalistic features about The A-Team on how viewers interpret the show. This view of intertextuality deflects attention away from how even the letter " $A$ " in the program's title draws upon an intertextual milieu that includes, but is in no way limited to, the popular phrases "Grade A egg" and " $A$ \#1," the use of " $A$ " to designate superior student work, the letter's placement at the beginning of the alphabet, or the designation outcast by the letter "A" in Hawthorne's Scarlet Letter. Audiences write the multitude of ways the letter " $A$ " has been used within the larger culture into the text of the show. The letter " $A$ " in the show's title, then, may inform the perception that the A-Team's actions are both positive ("A+" work) and marginal (The Scarlet Letter). To begin to appreciate the significance of the play of textuality in reading, one need only consider how the text would have been written/ perceived differently by viewers had it been titled The $C$-Team. 5 Thus, while Fiske describes intertextuality as an interpretive practice of audiences, he significantly limits the endless play of textuality that animates that practice. The danger in limiting analysis of media texts to explicitly linked texts is that it obscures and erases the more subconscious and therefore ideological textual linkages audiences make.

In addition to diluting the concept of intertextuality as interpretive practice, Fiske at times conflates it with the notion of "intertextuality as textual strategy" described in the introduction to this essay. To illustrate this point, it is necessary to quote Fiske's reading of Madonna's music video Material Girl at length:

Madonna's music video Material Girl provides us with a case in point: it is a parody of Marilyn Monroe's song and dance number "Diamonds are a Girl's Best Friend" in 
the movie Gentlemen Prefer Blondes: such an allusion to a specific text is not an example of intertextuality for its effectiveness depends upon specific, not generalized, textual knowledge. ... The video's intertextuality refers rather to our culture's image bank of the sexy blonde star who plays with men's desires for her and turns it to her advantage. It is an elusive image, similar to Barthes's notion of myth, to which Madonna and Marilyn Monroe contribute equally and from which they draw equally. The meanings of Material Girldepend upon its allusion to Gentlemen Prefer Blondes and upon its intertextuality with all texts that contribute to and draw upon the meaning of "the blonde" in our culture. (1987, p. 108)

In this example, Fiske goes to great lengths to stress that Madonna's parody of Marilyn Monroe is not an instance of intertextuality. Gesturing to Barthes, he argues that it requires no specific textual knowledge to read the video intertextually. While agreeing with Fiske that no such knowledge is required to read intertextually in general, it is curious that he selects a text that makes a specific, intentional intertextual reference to stress this point. The recognition of the specific reference to Gentlemen Prefer Blondes adds an additional "layer" of meaning to the readings of viewers who "catch" the reference.

Fiske further conflates the two views of intertextuality in Understanding Popular Culture when he suggests that popular texts are somehow more intertextual than the "highly crafted, completed, and self-sufficient" text found in "universities, museums, and art galleries" (1989, p. 123). Such a claim implies, in direct contrast to Barthes' view of intertextuality as interpretive practice, that intertextuality is inherent and unique to some texts. $\mathbf{R e}$ call that Barthes argues all texts are read intertextually by all audiences; intertextuality describes the general prac- tice of text construction undertaken by audiences. That certain texts, and not others, make explicit and intentional allusions to specific other texts is a process far different than the one described by Barthes. Though distinct, the two processes are not mutually exclusive. In concert with Barthes and Kristeva, that audiences always read/ write all texts intertextually is acceptable. However some texts also deploy intertextuality as a stylistic device in a manner that shapes how audiences experience those texts. This process is termed "intertextuality as textual strategy" and the following section ex plores the various ways it has been structured by media producers.

\section{Intertextuality as Textual Strategy}

While the concept of intertextuality as textual strategy is most commonly used in media studies, it is not entirely absent from literary theory. Morson (1981), for instance, classifies literary figures such as imitation and parody as "intertextual utterances" (p. 108-9). Gérard Gennette (1982) also conceives of intertextuality as a stylistic device by arguing that it reflects one of five possible "transtextual" relations a text may have with others. For Gennette it re fers specifically to the presence of one text in another by means of quotation, plagiarism, or allusion. Though the term intertextuality is largely absent in the work of Bakhtin (1984), Eco (1984), and Rose (1993), the concepts of "double-voiced words," the "already said," and "montage" provide alternatives for describing the way some texts incorporate others. Despite their diverse terminological preferences, each of these authors seem to agree that the frequency and intensity with which texts make intertextual utterances is a relatively recent phenomenon, a distinguishing attribute of postmodern texts. The term most widely adopted by media critics to describe the intertextual character of postmodern texts or contemporary media is what Jameson (1994) refers to as "pastiche."

The use of pastiche to describe the intertextual nature of contemporary media is troubling on at least two counts however. At present, media theorists employ pastiche as a blanket term to describe a whole range of intertextual strategies. In the process, they obfuscate the differences among several stylistic devices-devices that perform highly distinct rhetorical functions. In addition to applying the term too broadly, many cultural critics (Rose, 1993; Storey, 1998), and Jameson in particular, view pastiche as the failure of art-as an aesthetic practice that is entirely depthless, superficial, and uncritical.

Pastiche is, like parody, the imitation of a peculiar mask, speech in a dead language: but it is a neutral practice of such mimicry, without any of parody's ulterior motives, amputated of the satiric impulse, devoid of laughter and of any conviction that alongside the abnormal tongue you have momentarily borrowed, some healthy linguistic normality still exists. Pastiche is thus blank parody. (Jameson, 1994, p. 17)

Jameson's definition of pastiche reduces intertextuality to a neutral practice of compilation-one shorn of any critical engagement. As such, it fails to account for the ways that some texts rework others into their substance, how juxtaposition speaks comically, how audiences are transformed into sites of critical commentary, how textual inclusions function to oppose or celebrate the texts they steal from, and how the compilation of different styles may deliberately be used to create a new style. As Goodwin (1991) contends, some forms of textual incorporation simply cannot be explained as blank parody; therefore, categories to add to pastiche that demonstrate how popular culture equips audiences to make sense of their world and themselves are needed. To correct for these difficulties, in the section that follows three intertextual devices are identified.

These categories were generated while producing an educational video for use in Media Studies courses at Colorado State University. Using an Avid non-linear editing system (Media Suite Pro 3.0), a series of clips from television shows and films that made specific allusions to other media texts were spliced together. The primary texts with the specific texts that they alluded to were inter-cut and organized into categories based upon the nature of the allusions that they made. Three identifiable, though overlapping, categories emerged: parodic allusion, creative appropriation, and selfreflexive reference. Though each of these intertextual strategies is unique, they are often combined and intermingled. None of the strategies are entirely new, but they are finding their way into popular culture with a new intensity and frequency. To illustrate the expanding scope of these devices, examples from a number of different mass media are offered.

\section{Parodic Allusion}

Parodic allusion describes a stylistic device in which one text incorporates a caricature of another, most often, popular cultural text. The parodic text imitates or exaggerates prominent or representative features of the "original" text and incorporates those features as part of its own textuality. ${ }^{6}$ Though parodic allusion is similar to the ancient literary device of parody, it differs in 
two important ways. Whereas the aim of parody is to comment critically and/or comically on the original text usually by drawing attention to unspoken norms (Morson, 1981; Rose, 1993), parodic allusion offers no commentary on the original text. ${ }^{7}$ Rather, it seeks to amuse through juxtaposition-a goal that is enhanced by the reader's recognition of the parodic gesture. The audience is, in effect, transformed into the site of critical commentary; they are judged worthy by the text and subsequently themselves if they possess sufficient cultural knowledge to recognize the popular references.

Because these two devices have different aims, the manner in which they are executed also differs. Parody tends to be a self-contained text that is meaningful in isolation. Further, because parody counterposes the parodic text with the original in a way intended to discredit the original, the parodic text claims "semantic authority" over the original (Morson, 1981, p. 109). Dadaist parodies of other artistic movements, for instance, elevated themselves over those movements by commenting critically on the pretension of artists and the conventional responses of audiences. Parodic allusion, by contrast, makes no such claim to superiority over the original text nor is it generally a self-contained text. The reference to other texts characteristic of parodic allusion are woven into the fabric of a larger text or narrative. Moreover, because parodic allusion quizzes the audience's cultural knowledge, the larger text usually contains a collage of allusions. As with any test, the more questions (i.e., allusions) that one gets, the greater the sense of accomplishment. Textual collages featuring parodic allusion are rapidly taking hold in a variety of mass media.
As a stylistic device strategically utilized by producers of mass mediated texts, parodic allusion tends to manifest itself across the work of certain artists/auteurs. Since 1983, Weird Al Yankovic has been parodying the work of popular music artists such as $\mathrm{Ma}$ donna, Huey Lewis and the News, and Cyndi Lauper. While much of his early musical endeavors were more strictly parody, the eleventh track on his Dare to Be Stupid (1985) album was a significant step in the direction of parodic allusion. Unlike his previous work, which featured unusual lyrics set to the tune of chart-topping popular singles, track eleven-"Hooked on Polkas"incorporated the lyrics of twelve popular artists in one polka melody. ${ }^{8} \mathrm{~A}$ year later, Yankovic released Polka Party (1986), an album whose title track continued this style. Though "Polka Party," which excerpts songs such as Peter Gabriel's "Sledgehammer" and Phil Collins' "Sussudio," is humorous regardless of one's ability to identify the specific texts it refers to, exercising such cultural knowledge fosters feelings of superiority and belonging. Since not all listeners will recognize the allusions, successful identification of parodic references allows readers to mark themselves as musically literate and to identify themselves as part of a selec tive community (i.e., "true" Weird Al fans). Indeed, the pleasure of recognition is often directly proportional to the difficulty of identifying the allusion.

At present, parodic allusion is a much more pervasive stylistic device in television and film than in music. Nearly all of Mel Brooks' films, for instance, feature the device prominently. In only 94 minutes, High Anxiety (1977) spoofs twelve of Alfred Hitchcock's films, including a newspaper delivery by an agitated bellhop that mirrors the shower sequence in Psycho (1960) shotfor-shot. By 1987, the device was so central to Brooks' style that he squeezed 20 parodic references to film and television into Spaceballs (1987). ${ }^{9}$ The degree to which Brooks uses parodic allusion in cinema is equaled if not exceeded, however, in the television industry by Simpsons (1989) creator Matt Groening. In each 30-minute episode, The Simpsons regularly incorporates $15-20$ parodic allusions, ranging from Citizen Kane (1941) and Michael Dukakis' 1988 presidential campaign to Married Wit Children (1987-98) and the O.J. Simpson Bronco chase. While The Simpsons clearly held the pole position on intertextual references when it debuted ten years ago, recent programs such as Comedy Central's South Park (1997) and Fox's The Family Guy (1999-) are every bit as aggressive in their allusions to popular culture.

\section{Creative Appropriation or Inclusion}

Inclusion refers to a stylistic device in which one text appropriates and integrates a fragment of another text. Whereas parodic allusion creates an approximation or copy of the original text based upon its defining features inclusion actually reproduces a portion of the original text. In some, though not all, instances, the appropriated fragment is altered either through visual editing or audio mixing. The aim of inclusion also differs from parodic allusion; inclusion frequently comments on the text that it steals from or on that text's role in the larger culture. 10 "Each act of appropriation," writes Nunn (1997), "is a commentary on the work to which it refers and on the form ... a a whole" (p. 1). Depending upon how a fragment is juxtaposed with other fragments and the nature of those frag- ments, the type of commentary that inclusion renders ranges from critique to celebration. Technological developments in digital media have added sig nificantly to the growth of creative in clusion as a stylistic device in the past two decades. The introduction of inexpensive digital samplers in the music industry, for instance, fueled the emergence of an entire musical genre, hip-hop, which is marked by creative appropriation. Since inclusion often involves copyrighted material, its use as stylistic device has spawned a number of lawsuits concerned with intellectual property rights and freedom of expression.

One of the more famous cases in volves the self-proclaimed mediahacker band Negativland "who appropriate material from the airwaves and elsewhere to provoke and provide pointed commentary on the culture industry's machinations" (Negativland). In 1991, Negativland and SST records were sued over the band's single, "The Letter ' $U$ ' and the Numeral ' 2 '," which sampled U2's music, interviews with band members, and a particularly foulmouthed off-air moment from DJ Casey Casem. Though Negativland was ultimately forced to pay legal fees and damages totaling more than $\$ 90,000$, their single illustrates how the stylistic device of inclusion can function rhetorically as a mode of critique. By combining textual fragments in a manner that nvited a rereading of the band $\mathrm{U} 2$, Negativland denunciated what they saw as "the self-righteous and complacent image-world of the polite pop of the [U2] stars" (quoted in Herman \& Sloop, 1998, p. 7). Other bands, such as the New York trio De La Soul and the British based Ruthless Rap Assassins, have undertaken inclusion as a means to condemn specific cultural practices and social injustices. De La 
Soul exercises sampling to attack the macho and materialistic mentality of contemporary rap on their Stakes Is High (1996) album, while the Ruthless Rap Assassins, argues Storey (1998), use the device to critique the everyday racism of British society:

[The Ruthless Rap Assassins] would certainly reject Jameson's claim that their work is an example of postmodern pastiche. Their intertextual play of quotations is not the result of aesthetic exhaustion, but the telling combination of found fragments from a cultural repertoire which by and large denies their existence. These are ... fragments combined to damn those who have sought to deny them a voice within British culture. (pp. 191-2)

For bands such as De La Soul and the Assassins, the creative juxtaposition of fragments through inclusion reflects a new postmodern artistic style. Though as the Negativland case demonstrates, the legal system has been slow to legitimate creative appropriation as a valid artistic practice.

The film and television industries have largely avoided the legal pitfalls associated with creative appropriation by obtaining the pertinent copyright permissions before incorporating media fragments into their texts. One notable side effect of this approach has been a shift in tone toward the quoted material. Since copyright owners have the final say regarding their material, they consider the nature of the use before granting permission. As a result, intertextual gestures involving inclusion tend to be much more positive in the film and television industries than those in the music industry. In his tale of private eye Rigby Reardon, Carl Reiner's Dead Men Don't Wear Plaid (1982) appropriates and splices together clips from 17 noir films including classics such as Double Indemnity
(1944) and The Postman Always Rings Twice (1946). As reviews of the film make clear though, the tone of the appropriations is favorable. The Internet Movie Data Base describes Dead Man Don't Wear Plaid as a "celebration of the black-and-white movies of the 1940's and 50's," (Dead Man) and The Austin Chronicle hails it as "a tribute to the wonderful memories these films created in a generation" (Martini 1998). ${ }^{11}$ Perhaps the best example of creative inclusion functioning as tribute, however, was the HBO serie Dream On (1990-96), which emerged as a vehicle to showcase pre-1960 footage from television's "Golden Age."12 The show, which follows the daily interactions of book editor Martin Tupper illustrates Tupper's innermost thoughts and feelings with snippets from old TV comedies, dramas, and variety shows. ${ }^{13}$ In some cases then, creative appropriation functions to celebrate and promote the texts from which it steals.

\section{Self-Reflexive Reference}

In literature, self-reflexivity describes a mode of writing that deliberately draws attention to its fictional nature by commenting on its own activities "[S]elf-reflexivity," observes Campbell and Freed (1993), "destroys our suspension of disbelief in the magic of the moment ... it tweaks our anticipation and cynicism by adding a whole new level of self-centered amusement" ( $p$. 80). Jane Austen's comment (as narrator) that the problems confronting the protagonist must soon be resolved because Northanger Abbey has only a few pages left is self-reflexive; it reminds the reader that the hero is simply a character in a fictional book. Selfreflexive references represent an intertextual version of this literary mode. ${ }^{14}$ They describe a stylistic device in which one text refers to another text as a means of commenting on its own "cultural status, function, and history, as well as on the conditions of its circulation and reception" (Collins, 1995, p. 335). These self-aware references do not caricature another text as do parodic allusions nor do they appropriate an actual fragment of another text as do creative inclusions. Self-reflexive references are often subtle gestures that to be appreciated require specific knowledge of the text's production history, the character's previous credits, or popular reviews.

Gangsta rap affords an inherently self-reflexive form that involves MCs narrating and documenting their experiences in the rap culture. The frequent coastal jabs made infamous by rappers Tupac Shakur and the Notorious B.I.G. in the early $90 \mathrm{~s}$, for instance, provide the referent for Dr. Dre's song, "East Coast/West Coast Killas." With lyrics such as "The most scandalous, cut the bad apple, we can handle this/Coast trippin goin on throughout the business/East Coast West Coast anybody killer!/I don't give a fuck where you from I'ma Killa Hill-er/I got crews on both sides together/Deeper than the ocean and down for whatever," MC B-Real critiques the divisive state of rap while deterritorializing himself. A more direct reference to a specific text presents itself in the N.W.A. song "Gangsta, Gangsta" on their album Straight Outta Compton (1988). Devoted N.W.A. fans recognize that the chorus, "Gangsta! Gangsta! That's what they're yellin/It's not about salary, it's all about reality," refers to the title track on Eric B. and Rakim's album Paid in Full (1987) released the previous year. "Paid in Full" begins with Eric B. and Rakim discussing their relation to their record label and their motivation for rap- ping-to get paid. Their dialogue displays a self-awareness of their position within a system of commodity production, but does so without reference to another particular media text. "Gangsta Gangsta" by contrast draws attention to its modes of production by gesturing to "Paid in Full." N.W.A.'s intertextual allusion locates the reality of gangrelated violence as their motivation for rapping, thereby critiquing the view that rap is solely a commodity form.

While films such as John McTierman's Last Action Hero (1993) and Doug Liman's Swingers (1996) are littered with self-reflexive references, two scenes from Wes Craven's surprise horror-hit Scream (1996) illustrate the cinematic use of this device. When Casey's parents arrive home and realize that something is amiss, Casey's father instructs her mother to "go down the street to the Mackenzie's house." As serious horror fans would likely know, the line is a direct quotation from John Carpenter's horror-classic Halloween (1978). This intertextual reference accents the predictable and formulaic quality of horror films by reminding viewers of their recycled nature. Similarly, in the scene that precedes the film's final kill-fest, the remaining characters assemble to view Halloween. As they watch, the character of Randy describes the film's generic conventions, conventions that director Craven deliberately tampers with in the conclusion of Scream. Again, the intertextual reference highlights the formulaic quality of horror films, but it also elevates Scream over other horror films by demonstrating an awareness of (and ultimately breaking) the conventions that inform it.

A final example of self-reflexive reference comes from the Fox television program Ally McBeal (1997-). In September 1998, the New York Daily News 
described McBeal star Calista Flockhart as "waiflike" and speculated that she was "getting even skinnier." In the weeks that followed, an array of national newspapers and weekly magazines picked up the story and began speculating about whether or not Flockhart was anorexic. On 14 December 1998, Ally McBeal slyly attacked the public rumors concerning its feature character in the episode "Making Spirits Bright." As Ally crosses the office, she accidentally bumps into assistant district attorney Helen Grable from another David Kelley program The Practice. Helen blatantly sizes Ally up before insincerely saying, "Just admiring your outfit." As Helen leaves, she adds, "Maybe you should eat a cookie," to which Ally sarcastically retorts, "Maybe we could share it." Through this exchange, the character of Ally $\mathrm{McBeal}$ responds to public rumors initiated in the Daily News about actres Calista Flockhart. As the reference highlights the fictional status of the show, it also applauds loyal viewers fo getting the joke. The use of self-reflexivity, Williams (1988) notes, "at once breaks up the audience's willing suspension of disbelief by reminding them that they are watching television and reinforces their connection with the show through the feeling that this is a joke being shared by audience and character" (p. 92).

\section{Return of the Audience}

In mapping the concepts of intertextuality as interpretive practice and intertextuality as textual strategy, this discussion has largely driven audience and text apart. This section reflects an effort to reinfuse the two, and to consider more closely the nature of the interaction audiences have with texts marked by parodic allusion, creative appropria- tion, and self-reflexive reference. These three intertextual devices tend to work in tandem, and are characteristic of what Campbell and Freed (1993) term "postmodern" texts. The concern then is with how audiences engage and use postmodern texts. The view of media as symbolic system (Brummett, 1985; Burke, 1973; Croteau \& Hoynes, 1997; Rushkoff, 1996) affords a productive way to approach this question. This perspective suggests that audiences find in media texts the symbolic resources (i.e. mental equipment) for confronting and addressing the cultural anxieties, concerns, and demands of their everyday lives.

In Information Anxiety, Richard Wurman (1989) documents the widespread feelings of the alienation and fragmentation that pervade contemporary youth culture. Since identity has always been closely tied to self-location, Collins (1995) posits that such feelings of displacement may largely be the result of radical changes in how we experience time and space-changes brought on by the rise of the new information technologies. E-mail, instant messaging, simulations, and virtual environments reflect only a few of the technological innovations that have tampered with traditional views of time and space. While simply living in a particular physical place may no longer furnish the sense of community and self that it once did, the media provide resources for building coherent, if mutable, identities (see Kellner, 1995). The intertextual allusions found in postmodern texts allow viewers to exercise specialized knowledge and to mark their membership in particular cultures. "To belong to the MST 3K [Mystery Science Theater 3009 culture," notes Rushkoff (1996), "is to understand at least a majority of the literally hundreds of refer- ences per show" (p. 235). To catch the majority of intertextual gestures in Scream is to mark one's identity as a horror-film buff, in Straight Outta Compton as gangsta rap buff, and in Spaceball as a science-fiction buff.

Because of the Internet, the game of intertextuality is not only a marker of cultural identity, but also an opportunity to participate in community. All of the media texts examined in the previous section of this essay have enormous Internet followings. Fans gather online (and in the case of television, often while the program is in progress) to share their intertextual observations, exchange "insider" information about production history, and discuss related media texts. ${ }^{15}$ The same is decidedly not the case with less intertextual forms such as CBS's Dr. Quinn, Medicine Woman (1993-98) and Costner's film Dances with Wolves (1990). Intertextual media encourage viewers to identify with others in a manner that less consciously intertextual media do not. In addition to fostering community, intertextual devices frequently contribute to a sense of self-satisfac tion. Historically, popular art forms such as television have been disparaged by critics (Postman, 1985) who characterize them as "mindless entertainment" and a "waste of time."16 The self-reflexivity of intertextual TV, however, serves "to distance these programs from the stigmatized medium and to announce that they are superior to the typical trash available on TV" (Bianculli, 1992, p. 15). Thus, intertextual media afford a guilt-free interaction with "higher" art while congratulating viewers for getting the joke.

The epistemological implications of intertextual media are as dramatic as those associated with identity. As the prevailing symbolic forms in Ameri- can culture change, so too do the ways that audiences engage and interpret them. The collage-like, participatory nature of intertextual media fosters an aggregative rather than sequential way of seeing and knowing. Instead of processing data as a finite set of causal relations, audiences favor a spatial orientation in which everything is related to everything else. ${ }^{17}$ Unlike rigidly linear texts in which meaning is intricately tied to sequence, highly intertextual forms can be entered at almost any point (Soja, 1989, p. 2). This nonlinearity corresponds closely to hypertext logic (Landow, 1997) and equips audiences to surf-to piece together meaning from a discontinuous set of fragments (Rushkoff, 1996, pp. 49-50). With the total of all printed knowledge doubling every eight years (Wurman, 1989 , p. 35), the logic and practice of surfing are becoming increasingly vital to locating, retrieving, and processing desired information. Through the routine consumption and use of intertexual media, audiences are constituted as "sophisticated bricoleurs" (Storey, 1998, p. 194). The fan-related Web sites that flourish around consciously intertextual media are themselves constructed from the shards of culture, and recent research in the area of remote control use (Bellamy \& Walker, 1996) suggests that television viewing may be a complex act of text construction for many young people. ${ }^{18}$ Rather than consuming texts as unified wholes, audiences piece together fragments of texts to meet their individual psychological needs.

Intertextual media also appear to foster an "ironic sensibility" by equipping audiences with a heightened awareness of the way texts inflect generically, culturally, and politically upon other texts. While all audiences read intertextually, audiences who 
spend significant time with texts characterized by intertextuality as a stylistic device develop a more self-conscious intertextual reading formation. Audiences who regularly engage with intertextual devices not only become more sophisticated at reading them, but also more sophisticated at deploying them. ${ }^{19}$

\section{Conclusion}

This essay has examined the two very disparate ways that media scholars employ the concept of intertextuality and explored how both uses suffer when they are unknowingly conflated. In investigating the features of intertextuality as interpretive practice, this essay sought to expand the way media critics conceptualize the reading formations of audiences. The lifetime of unconscious textual baggage audiences bring to their reading of mediated texts is more central to the process of meaning construction than explicitly linked secondary texts such as journalistic features or tertiary texts such as gossip. Reading intertextually is an ideological process, but more research is needed to understand how audiences internalize textual ideologies and how those ideologies are activated by texts during the reading process. One particularly interesting and valuable research area might involve looking at how individual readers reconcile the competing ideologies activated by reading a text.

In probing the notion of intertextuality as motivated textual strategy, parodic allusion, creative inclusion, and self-reflexive reference were estab-

\section{Notes}

'We regard it as more than coincidence that the centering of the audience as a site of textual production and the expanding role of intentional allusion in media have developed concurrently Indeed, this perception informs the organization of our essay and the, at times, extensive account of previous literature. Our aim is to give a sense of both how these conceptions developed, and why they developed when they did. Perhaps the theory of the 'active audience' came to replace previous conceptions of audience activity not because it was a more accurate descriptor of what audiences have always done, but because it is a more accurate descriptor of what audiences have more recenlly done. We are suggesting that as the nature of texts themselves have changed, the way audiences read texts has changed as well.

${ }^{2}$ Schirato and Yell (1996) define intertextuality as "the process of making sense of texts in reference to their relations with other texts" (p.92), and as "the different cultural literacies we bring to any reading of a text" (p. 217). By contrast, Suleinan (1990) defines intertextuality as "the presence, either explicit (as in direct quotation, identified as such) or implicit (as in allusion parody, imitation) of one text in another" (p. 219). The former refers to something audiences do, and the latter refers to something authors do.

${ }^{3}$ As Barry Brummett demonstrates, the notion of intertextuality as stylistic device is not limited to media texts. "Afrocentric culture," according to Brummett, "expects that texts will borrow from other texts freely, using a strategy called intertextuality. Critics should be on the lookout for that strategy.... For example, much of the speaking of Martin Luther King, Jr., was intertextual. He
wove into a speech many brief passages from the Bible, proverbs, maxims, and his other speeches" wove into a speec

${ }^{4}$ For a more detailed discussion of how discursive communities shape the practice of reading intertextually, see Porter (1986)

${ }^{5}$ ABC's farcical western $F$ Troop (1965-67) provides another example of how meaning is informed by a vast array of textual knowledges. No doubt the many meanings of the letter " $F$ " contributed to the perception of the cavalrymen on this series as bumbling and inept.

${ }^{6} \mathrm{We}$ are using the term "original" as a way to distinguish the parodic text from the parodied tex and have inscribed the term in quotation marks to indicate that the parodied text (consistent with view of intertextuality as interpretive practice) is itself comprised of other texts.

"In literary theory, works of fiction that comment or reflect upon another text are labeled "meta-fictional" while texts that incorporate other texts through imitation or quotation are termed "intertextual." In contemporary theory, parody is conceptualized as both meta-fictional and intertextual (Rose, 1993, pp. 99, 282-283). We are arguing that parodic allusion lacks the meta-fictional dimension.

8Popular references include Euday Bowman's "12th Street Rag," ZZ Top's "Sharp Dressed Man," Tina Turner's "What's Love Got to Do With It," Hall and Oates' "Method of Modern Love," Yes' "Owner of a Lonely Heart," Duran Duran's "Reflex," Nena's "99 Luftbalons," Kenny Loggins' "Footloose," Twisted Sister's "We're Not Gonna Take It," Quiet Riot's "Mental Health," Frankie Goes to Hollywood's "Relax," and The Jacksons' "State of Shock."

${ }^{9}$ Media references include It Happened One Night (1934), The Wizard of Oz (1939), Dumbo (1941), One Froggy Evening (1955), The Bridge Over the River Krwai (1957), Lawrence of Arabia (1962), Fantastic Voyage (1966), Star Trek (1966), Planet of the Apes (1968), 2001: A Space Odyssey (1968), Jawe (1975), Star Wars (1977), Fantasy Island (1978), Alien (1979), The Empire Strikes Back (1980), The Hitchhiker's Guide to the Galaxy (1981), Return of the Jedi (1983), The Transformers (1984), Transformers: The Movie (1986), and Max Headroom (1987).

${ }^{10}$ Creative appropriation is a prominent strategy in feminist art and is frequently used to illustrate the patriarchal ideology of the text from which it steals (see especially Suleiman, 1990). Ms. magazine provides an excellent example of the use of this strategy in media. Each month, the magazine publishes reader-submitted items in a section titled "No Comment." The "No Comment" feature exposes the sexism of the submitted items simply by placing them in a new contex that invites an oppositional reading. For a more extended explanation, see Croteau and Hoynes (1997, pp. 252-254).

"One of the most novel uses of creative appropriation occurs in Steven Soderbergh's The Limg (1999). In this film, flashbacks to the main character Wilson (Terrence Stamp) in his youth are accomplished by incorporating clips from Ken Loach's Poor Cow (1967), in which a then much 
younger Terrence Stamp played a petty hood named Wilson. Creative appropriation in this case functions not only as tribute, but also as a device that imbues the protagonist with historical depth. We are indebted to Karen Huck for this example.

${ }^{12}$ According to Bianculli (1996), "[Dream On] was commissioned by MCA as a clever way to recycle some of the other wise unused stuff in its vaults" (p. 95). Executive producer, John Landis "Dtimates that the writers had over 800 half-hours worth of MCA shows upon which to draw. See "Dream On Inspiration." Retrieved June 16, 1999 from the World Wide Web: http:// www.mca.com/tv/dreamon/landis_interview.html.

${ }^{13}$ Appropriations include programs such as the Jane Wyman Show (1955-58), G. E. Thealer (1953-62), Alcola Premiere (1961-63), and Ford Startime (1959-60).

${ }^{14}$ We recognize that the term "self-reflexive" is redundant since "reflexive" implies selfawareness. But in keeping with the current literature, we have decided to use this label anyway.

${ }^{15}$ This exchange of information is closely tied to prestige. "Within the informational economy of the net, knowledge equals prestige, reputation, power. Knowledge gains currency through circulation on the net, and so there is a compulsion to be the first to circulate new information and to be among the first to posses it" (Jenkins, 1995, p. 59).

${ }^{16}$ The perception of television's "simple-mindedness" is reflected in the characterization of viewers as "couch potatoes." Pedagogically, this perception is reinforced in formal educational spheres where reading is still taught, valued, and rewarded over viewing and surfing. Indeed, liter wher literacy continues to be linked almost exclusively to literature in elementary education. Given the low social value attributed to media, heavy media use is a significant source of guilt in contemporary culture. Self-reflexive forms work to resolve this guilt by distancing themselves from forms that are unaware of their technical conventions and modes of appeal.

${ }^{17} \mathrm{~A}$ good example of this logic is the introduction of fractals in mathematics.

${ }^{18}$ Research indicates that when young viewers lose interest in a television program they use the remote control device to fashion their own program, flipping back and forth between multiple shows (Bellamy \& Walker, 1996, pp. 107-115).

${ }^{19}$ Many of the fan-related Web sites dedicated to Comedy Central's South Park, for example, feature original, self-produced parodies of other media using the characters of the show. At www.sweet.com, users can download high-resolution movie poster parodies such as The Fat Red Line, Saving Privale McCormick, and Park Trek. At www.infinicorp.com/babylonpark/, users can read elaborate narratives concerning South Park characters that parody the show Babylon5. The fan-related Web pages for other highly intertextual media also frequently feature products that illustrate exceptional skill at creating parody.

${ }^{20} \mathrm{We}$ are compelled by both Burke's (1973) contention that symbolic forms (satire, parody, and tragedy, for instance) function as equipment for living, as stylistic medicines for confronting the anxieties of social life and for shaping one's sense of self, and the McLuhanite assumption (Chesebro \& Bertelsen, 1996; Altheide \& Snow, 1991) that different media promote different ways of "seeing" the world. To the extent that a single medium, such as television, utilizes various forms, such as drama and comedy, it is vital that critics explore the entire range of form-medium combinations and the unique symbolic equipments that each combination affords. We would suggest that the television series Dr. Quinn, Medicine Woman and The Simpsons, for instance, provide viewers with very different sets of resources for forging their identities because of their unique combinations of medium and form.

\section{References}

Altheide, D., \& Snow, R. (1991). Media worlds in the postjournalism era. New York: Aldine De Gruyter. Bark, E. (1998, November 16). "Chicago Hope" bares the needle, pokes fun in "Cheek." The
Denver Post, p. 9F.
Barthes, R. (1988). Image, music, text (S. Heath, Trans.). New York: The Noonday Press. (Original work published 1977)

Bellamy, R., \& Walker, J. (1996). Television and the remote control: Grazing on a vast wasteland. New York: Guilford.

Bianculli, D. (1992). Teleliteracy: Taking television seriously. New York: Continuum.

Bianculli, D. (1996). Dictionary of teleliteracy: Television's 500 biggest hits, misses, and events. New York: Continuum.

Brummett, B. (1985). Electric literature as equipment for living: Haunted house films. Critical Studies in Mass Communication, 2, 247-261.

Brummett, B. (1994). Rhetoric in popular culture. New York: St. Martin's Press.

Burke, K. (1973). The philosophy of literary form: Studies in symbolic action. Berkeley: University of California Press.

Campbell, R., \& Freed, R. (1993). "We know it when we see it": Postmodernism and television. Television Quarterly, 26, 75-87.

Chesebro, J., \& Bertelsen, D. (1996). Analyzing media: Communication technologies as symbolic and cognitive systems. New York: Guilford Press.

Collins, J. (1992). Television and postmodernism. In R. Allen (Ed.), Channels of discourse, reas sembled: Television and contemporary criticism (2nd ed., pp. 325-353). Chapel Hill: University of North Carolina Press.

Collins, J. (1995). Architectures of excess: Cullural life in the information age. New York: Routledge.

Croteau, D., \& Hoynes, W. (1997). Media/sociely: Industries, images, and audiences. Thousand Oaks: Pine Forge Press.

“Dead Men Don't Wear Plaid," http://us.imdb.com/Title?0083798, accessed 16 June 1999

"Dead Men Plaid," http://weeklywire.comm, accessed 16 June 1999.

Derrida, J. (1976). Of grammalology (G. Spivak, Trans.). Baltimore: John Hopkins University Press. (Original work published 1967).

Eco, U. (1984). The name of the rose. New York: Harcourt Brace Jovanovich.

Fink, M. (1998, September 20). They got skin and bones to pick with Calista. New York Daily News. Fiske, J. (1987). Television culture. New York: Routledge.

Fiske, J. (1989). Understanding popular culture. Boston: Unwin Hyman.

Genette, G. (1982). Palimpsestes: La litterature au second degré. Paris: Seuil.

Goodwin, A. (1991). Popular music and postmodern theory. Cultural Studies, 5, 173-185.

Goodwin, J. (1994). Akira Kurosawa and intertextual cinema. Baltimore: Johns Hopkins University Press.

Griffin, G. (1998, May 4). Goin' south: Cartoon show. Copley News Service.

Hawkes, T. (1977). Structuralism and semiotics. Berkeley: University of California Press

Herman, A., \& Sloop, J. (1998). The politics of authenticity in postmodern rock culture: The case of Negativland and the letter " $U$ " and the numeral "2." Critical Studies in Mass Communication, 15, $1-20$

Jameson, F. (1994). Postmodernism, or, the cultural logic of late capilalism. Durham: Duke University Press.

Jenkins, H. (1995). "Do you enjoy making the rest of us feel stupid?": alt.tv.twinpeaks, the trickster author, and viewer mastery. In D. Lavery (Ed.), Full of secrets: Critical approaches to twin peaks (pp. 51-69). Detroit: Wayne State University Press. 
Kellner, D. (1995). Media culture: Cultural studies, identity and politics between the modern and the postmodem. New York: Routledge.

Kristeva, J. (1986a). Revolution in poetic language. In T. Moi (Ed.), The Kristeva reader (pp. 89-136) New York: Columbia University Press.

Kristeva, J. (1986b). Word, dialogue and novel. In T. Moi (Ed.), The Kristeva reader (pp. 34-50). New York: Columbia University Press.

Landow, G. (1997). Hypertext 2.0: The convergence of contemporary critical theory and technology. Baltimore: John Hopkins University Press.

Makaryk, I. (1995). Encyclopedia of contemporary literary theory: Approaches, scholars, terms. Toronto: University of Toronto Press.

Martini, A. (1998, March 2). Dead Men Don't Wear Plaid. The Austin Chronicle. [Online] Available: http://weeklywire.com [1999, June 16].

Morley, D. (1993). Television, audiences and cultural siudies. New York: Routledge.

Morson, G. (1981). The boundaries of genre: Dostoevsky's diary of a writer and the traditions of literary ulopia. Evanston: Northwestern University Press.

Negativland. Retrived June 16, 1999 from the World Wide Web: http://www.altculture.com/ aentries $/ \mathbf{n} /$ negativlan.html.

Nunn, E. (1997, April). Beyond gangsta rap: Narrative power and the post-gangsta aesthetic. Paper presented at the International Conference on Narrative, University of Florida.

Payne, M. (Ed.). (1996). A dictionary of cultural and critical theory. Cambridge: Blackwell.

Porter, James E. (1986). Intertextuality and the discourse community. Rhetoric Review, 5, 34-47.

Postman, N. (1985). Amusing ourselves to death: Public discourse in the age of show business. New York: Penguin Books.

Rose, M. (1993). Parody: Ancient, modern, and post-modern. Cambridge University Press.

Rushkoff, D. (1996). Playing the future: How kids' culture can teach us to thrive in an age of chaos. New York: HarperCollins.

Schirato, T., \& Yell, S. (1996). Communication and cultural literacy: An introduction. St. Leonards, Australia: Allen \& Unwin.

Scholes, R. (1989). Protocols of reading. New Have: Yale University Press.

Soja, E. (1989). Postmodern geographies: The reassertion of space in critical social theory. New York: Verso. Storey, J. (1998). An introduction to cultural theory and popular culture, (2nd ed.). Athens: University of
Georgia Press.

Suleiman, S. (1990). Subversive intent: Gender, politics, and the avant-garde. Cambridge: Harvard University Press.

White, M. (1992). Ideological analysis and television. In R. Allen (Ed.), Channels of discourse, reassembled: Television and contemporary criticism (2nd ed., pp. 161-202). Chapel Hill: University of North Carolina Press.

Williams, J. (1998). When you care enough to watch the very best: The mystique of moonlighting. Journal of Popular Film and Television, 16,90-100.

Wurman, R. (1989). Information anxiety. New York: Doubleday.

\section{Movies as Equipment for Living: A Developmental Analysis of the Importance of Film in Everyday Life}

\author{
Stephen Dine Young
}

$\square$-The use of movies as "equipment for living" is considered in the context of several scholarly traditions: textual analysis, viewer-effects research, cultural studies, and gratifications research. In light of these traditions, a developmental approach to symbolization is advanced as one means toward understanding how viewers apply their interpretations of films to their everyday lives. An open-ended interview methodology was utilized that encouraged twelve participants to examine their autobiographical recollections of their film viewing experiences and to generate examples of when movies have had an impact in their lives. These self-reports were used to exemplify three developmental categories which address the relationship between self (viewer) and other (film) in regard to film's perceived functions: 1) undifferentiated, 2) differentiated, and 3) integrated. Underlying sociocultural considerations evident in the self-reports are also examined. The implications of a symbolic-developmental approach for other media research traditions are discussed.
So Dorothy goes through hell before she gets back to Kansas. But the bottom line was, she made it. And what I remember feeling when she clicked those heels was that you have to have faith and be a believer, for real, or nothing will ever materialize.... Dorothy had a good heart and it was in the right place, which is why I suppose she won out over the evil witch. I've learned that one, too.... So I think I

Stephen Dine Young is an Assistant Professor in the Psychology Department at Hanover College, Hanover, IN, 47243. An earlier version of this paper was presented at the 1996 Annual Convention of the American Psychological Association. This article was drawn from a dissertation completed at the Francis L. Hiatt School of Psychology, Department of Psychology, Clark University, under the direction of Bernard Kaplan. vowed when I was little to try to be a good person. An honest person. To care about thers and not just myself. ... I would have to ... believe that if I did the right things, I would never stray too far from my Yellow Brick Road. (McMillan, 1991, pp. 262-263)

Novelist Terry McMillan's account of the impact of The Wizard of Ozon her life speaks to a familiar form of human experience. Many people can remember at least one movie that has transcended cinema's mundane ability to entertain and left a deeper, lasting impression. Those experiences in which art forms such as film transform members of the audience will be the focus of this study.

Relatively few scholarly works on art take transformation to be the central 